IEEE Transactions on Industrial Electronics, vol.63, no.9, pp.5879-5890, Sept. 2016.

http://ieeexplore.ieee.org/document/7458864/

ISSN: 0278-0046 (Print) 1557-9948 (Online)

DOI: $10.1109 /$ TIE.2016.2558141

This material is posted here with permission of the IEEE. Such permission of the IEEE does not in any way imply IEEE endorsement of any of Group of Energy and Power Electronics, University of Minho, products or services. Internal or personal use of this material is permitted. However, permission to reprint/republish this material for advertising or promotional purposes or for creating new collective works for resale or redistribution must be obtained from the IEEE by writing to pubs-permissions@ieee.org. By choosing to view this document, you agree to all provisions of the copyright laws protecting it.

(C) 2014 IEEE 


\title{
Model Predictive Control Applied to an Improved Five-Level Bidirectional Converter
}

\author{
Vítor Monteiro, Student Member, IEEE, João C. Ferreira, Senior Member, IEEE, \\ Andrés A. Nogueiras Meléndez, Senior Member, IEEE, and João L. Afonso, Member, IEEE
}

\begin{abstract}
This paper presents an improved five level bidirectional converter (iFBC) controlled by finite control set model predictive control (FCS-MPC). This control strategy consists in using the discrete time nature of the iFBC to define its state in each sampling interval. Using FCS-MPC the switching frequency is not constant; however, it is suitable to follow the current reference with low total harmonic distortion (THD). The iFBC prototype that was specially developed for obtaining experimental results is described in detail along the paper, as well as its principle of operation, power theory, and current control strategy. The iFBC was experimentally validated connected to the power grid through a second order $L_{f} C_{f}$ passive filter, operating as an active rectifier and as a grid tie inverter. For both operation modes, the experimental results confirm the good performance (in terms of efficiency, low current THD and controlled output voltage) of the iFBC controlled by FCS-MPC.
\end{abstract}

Index Terms-Bidirectional, Five Level Converter, Model Predictive Control, Power Quality.

\section{INTRODUCTION}

A CTIVE rectifiers have some important advantages when compared with the traditional solutions based on diode rectifiers and multi-pulse rectifiers [1]. These advantages are the low total harmonic distortion (THD) of the grid current, the high total power factor and the controlled output voltage (dc-link) $[1][2][3]$. The power-factor-correction (PFC) converter, composed of a diode-bridge rectifier followed by a dc-dc boost-type converter, is the most employed converter when the control of these three parameters is required. Similar topologies to meet these requirements can employ a dc-dc

Manuscript received May 31, 2015; revised December 24, 2015 and February 26, 2016; accepted March 18, 2016. This work was supported in part by the FCT-Fundação para a Ciência e Tecnologia in the scope of the project: PEst-UID/CEC/00319/2013. Mr. Vítor Monteiro was supported by the doctoral scholarship SFRH/BD/80155/2011 granted by the FCT agency.

Vítor Monteiro and João L. Afonso are with Dept. Industrial Electronics, Centro Algoritmi, University of Minho, Guimarães, 4800058. Portugal; emails: vmonteiro@dei.uminho.pt and jla@dei.uminho.pt. (corresponding author phone: +351 253510 392; fax: +351 253510 189; e-mail: vmonteiro@dei.uminho.pt).

João Ferreira is with Centro Algoritmi, University of Minho and GulAAISEL, Lisbon Portugal, Rua Conselheiro Emídio Navarro 1, Lisboa, 1900-049, Portugal; e-mail: jferreira@deetc.isel.ipl.pt.

Andrés Meléndez is with Departamento de Tecnología Electrónica, University of Vigo, Vigo, 36310, Spain; email: aaugusto@uvigo.es. three-level converter [4], a dc-dc buck-boost converter [5], and a buck-flyback converter [6]. On the other hand, in order to avoid the front-end diode-bridge rectifier, the PFC bridgeless converters are analyzed in [7]. A review about PFC bridgeless converters is presented in [8], where the well-known PFC symmetrical and asymmetrical bridgeless converters are included [9][10]. Other relevant groups of PFC converters are the interleaved and the multi-level $[11][12][13][14]$. The main advantage of the multi-level converters is the possibility of reducing the voltage stress in the semiconductors, and the volume and size of the passive filters [15][16]. In this context, this paper presents an improved five-level bidirectional converter (iFBC). The circuit topology of the iFBC is presented in Fig. 1.

The most famous five-level converter is the cascade H-Bridge, composed by two H-Bridges [17][18]. Comparing with the iFBC, it can also operate in bidirectional mode, but it has two independent dc-links and requires more hardware. A new topology of a unidirectional single-phase five-level converter based on the flying-capacitor rectifier is presented in [19]. However, this new topology can only be connected to the power grid as an active rectifier and not as a grid-tie inverter. Similarly, a new topology of a five-level inverter using a single dc source cascading a flying capacitor and an H-Bridge converter is presented in [20]. However, this is a three-phase topology that cannot be adopted for single-phase systems. Moreover, each phase requires eight IGBTs and two capacitors, besides the dc-link. In this sequence, a novel strategy to control a five-level inverter using a flying-capacitor asymmetric H-Bridge converter is proposed in [21]. A novel topology of a five-level inverter, which uses two additional IGBTs comparing with the H-Bridge converter is presented in [22]. Relatively to the iFBC it requires less two diodes,

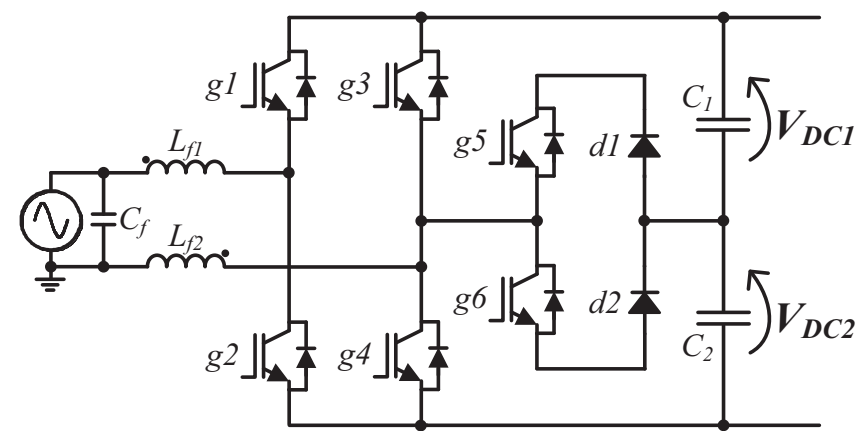

Fig. 1. Topology of the improved five-level bidirectional converter (iFBC). 
however, depending on the application (connected to the power grid as an active rectifier or as a grid-tie inverter), the power in the dc-link sources may not be balanced. Besides, this topology uses an IGBT between the two sources of the dc-link, which can be a great disadvantage for some applications, e.g., interface from renewables, as photovoltaics. Moreover, this topology, at most, can be expanded only to a seven-level topology. A new buck-boost five-level converter is presented in [23][24]. However, it also has the dc-link constituted by two independent sources, like the cascade $\mathrm{H}$-Bridge converter, limiting its range of applications. A bidirectional five-level converter specially dedicated for photovoltaic applications is proposed in [25], however, it requires more two IGBTs and two diodes comparing with the iFBC. A new single-phase five-level inverter with a dead-beat controller is presented in [26]. This converter uses a split dc-link and is composed of an H-Bridge converter and a bidirectional cell connected between the middle point of the dc-link and a leg of the H-Bridge converter. This new inverter was experimentally validated only operating as an inverter [26]. In counterpart, the iFBC uses an enhanced bidirectional cell, i.e., instead of an IGBT with a diode-bridge rectifier, there are two legs, one formed by IGBTs and another by diodes. In the proposed improved bidirectional cell, only one IGBT is used at each time, i.e., it is possible to split the losses among the two IGBTs. Moreover, with the improved bidirectional cell, during each sampling period, instead of an IGBT and two diodes, a branch with an IGBT and a diode is used. This implies that, using the improved bidirectional cell, the losses in the diodes are reduced to the half. Another advantage is the possibility of operating as an active rectifier or as a grid-tie inverter. During the operation as an active rectifier, the iFBC works with a sinusoidal grid current, in phase with the power grid voltage, and with a controlled output voltage. On the other hand, when operating as a grid-tie inverter the iFBC also works with a sinusoidal grid current, but in phase opposition with the power grid voltage. In both operation modes, the voltage produced by the iFBC (i.e., the voltage between the $L_{f} C_{f}$ passive filter and the IGBTs leg) can assume five different levels $\left(+V_{D C},+V_{D C} / 2,0,-V_{D C} / 2\right.$, and $\left.V_{D C}\right)$. Moreover, adding additional IGBTs and diodes to the iFBC the number of levels can be increased indefinitely. For a topology with $n$ distinct voltage levels, the number of IGBTs is $n-1$, the number of diodes is $n-3$, and the number of dc-link capacitors is $((\mathrm{n}+1) / 2)-1$.

The classical current control strategies for active rectifiers or grid-tie inverters are mainly based on hysteresis-band controllers and linear-control with pulse-width modulation [27][28]. However, nowadays, due to the advances in microcontrollers, increasingly, predictive schemes are proposed to control power electronics converters. When compared with the classical current control strategies, predictive schemes are more intuitive and allow to include the nonlinearities of the controlled system; however, the digital implementation is more complex [29]. In this context, several predictive control strategies can be implemented, including dead-beat control, hysteresis based, trajectory based, and model predictive control (MPC), where the continuous control set and the finite control set is included [29]. In order to control the grid current of the $\mathrm{iFBC}$, any of the aforementioned current control strategies can be used. However, using a modulator to obtain the five voltage levels is complex. Therefore, a current control strategy that does not require a modulator should be selected, e.g., trajectory based or MPC with finite control set. Comparing both current control strategies, in the scope of this paper, the MPC with finite control set (FCS-MPC) is used to define the state of the iFBC in each sampling period, due to its simplicity, flexibility, and possibility to include nonlinearities (e.g., the input $L_{f}$ passive filter) [30][31]. Taking into account that the grid current is the variable that should be controlled during both operation modes (active rectifier and grid-tie inverter), a cost function to minimize the error between the measured grid current and its reference is used [32]. According to the converter and the final application, it is important to note that the cost function can also be used to minimize the switching frequency, output voltage, torque, flux, and active or reactive power [33]. In the FCS-MPC a longer prediction horizon (more than one) and a delay compensation can also be considered [34]. As example, a new delay time compensation method for the MPC, applied to a voltage source inverter in order to control an induction motor, is proposed in [35]. A review about the use of FCS-MPC for power electronics applications is presented in [33], where it is shown that it can be successful applied to ac-dc, ac-ac, dc-dc, and dc-ac converters. Taking into account its versatility, the MPC has been employed in a wide range of applications [36][37][38]. It can be applied to control the grid current in voltage-source and current-source converters [39][40], and for different applications, e.g., uninterruptible power supplies and shunt active power filters [41][42]. In the scope of this paper, the FCS-MPC was validated with a proposed improved bidirectional multilevel converter (iFBC) during the operation as an active rectifier and as a grid-tie inverter. The main contributions of this paper are: an improved bidirectional cell associated with a H-Bridge converter to perform a five-level converter (iFBC); The experimental validation of the iFBC, i.e., a converter capable of producing five distinct voltages $\left(+V_{D C},+V_{D C} / 2,0,-V_{D C} / 2\right.$, and $\left.-V_{D C}\right)$; The experimental validation of the FCS-MPC applied to the iFBC during the operation as an active rectifier (i.e., controlling the grid current and the dc-link voltage) and as a grid-tie inverter (i.e., controlling the grid current).

The rest of this paper is organized as follows. Section II describes the principle of operation of the iFBC during the operation as an active rectifier and as a grid-tie inverter. In section III the FCS-MPC is described in detail, i.e., the power theory, the predictive model, the cost function and the gate pulse patterns. Section IV presents the developed iFBC prototype, while in section $\mathrm{V}$ the experimental validation of the FCS-MPC applied to the iFBC in both operation modes is presented. Finally, in section VI the main conclusions are presented. 

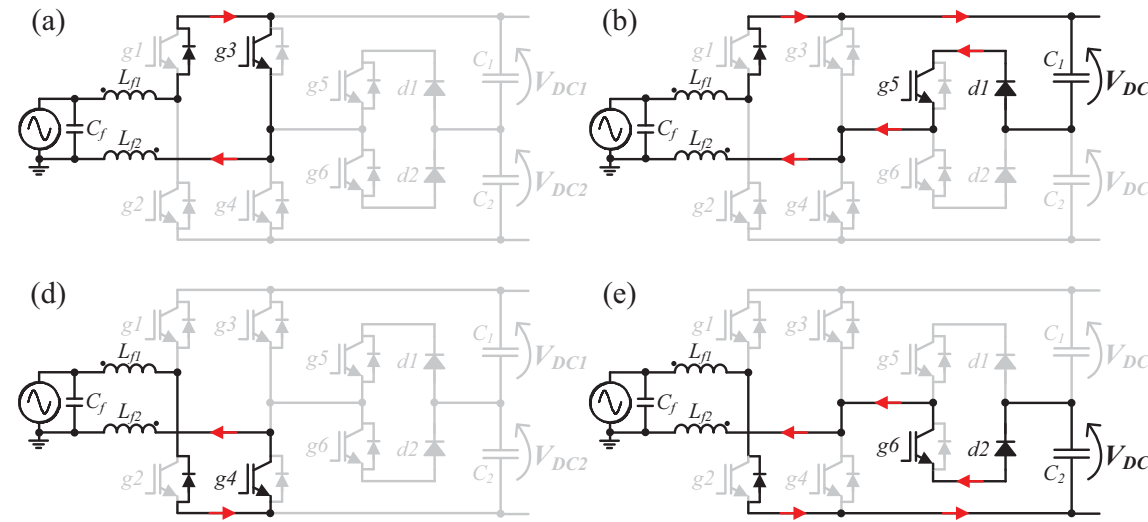

(e)
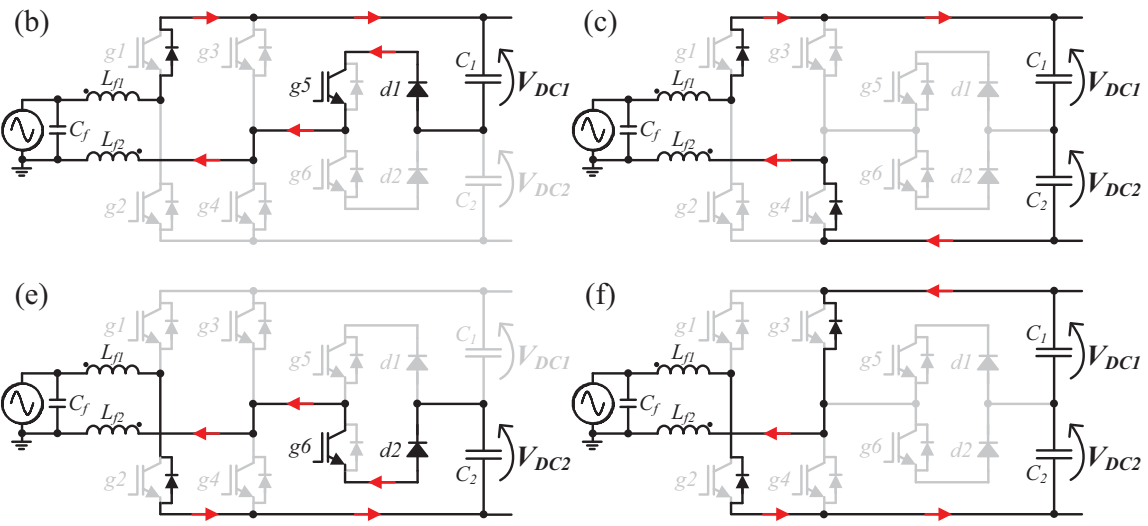

(f)
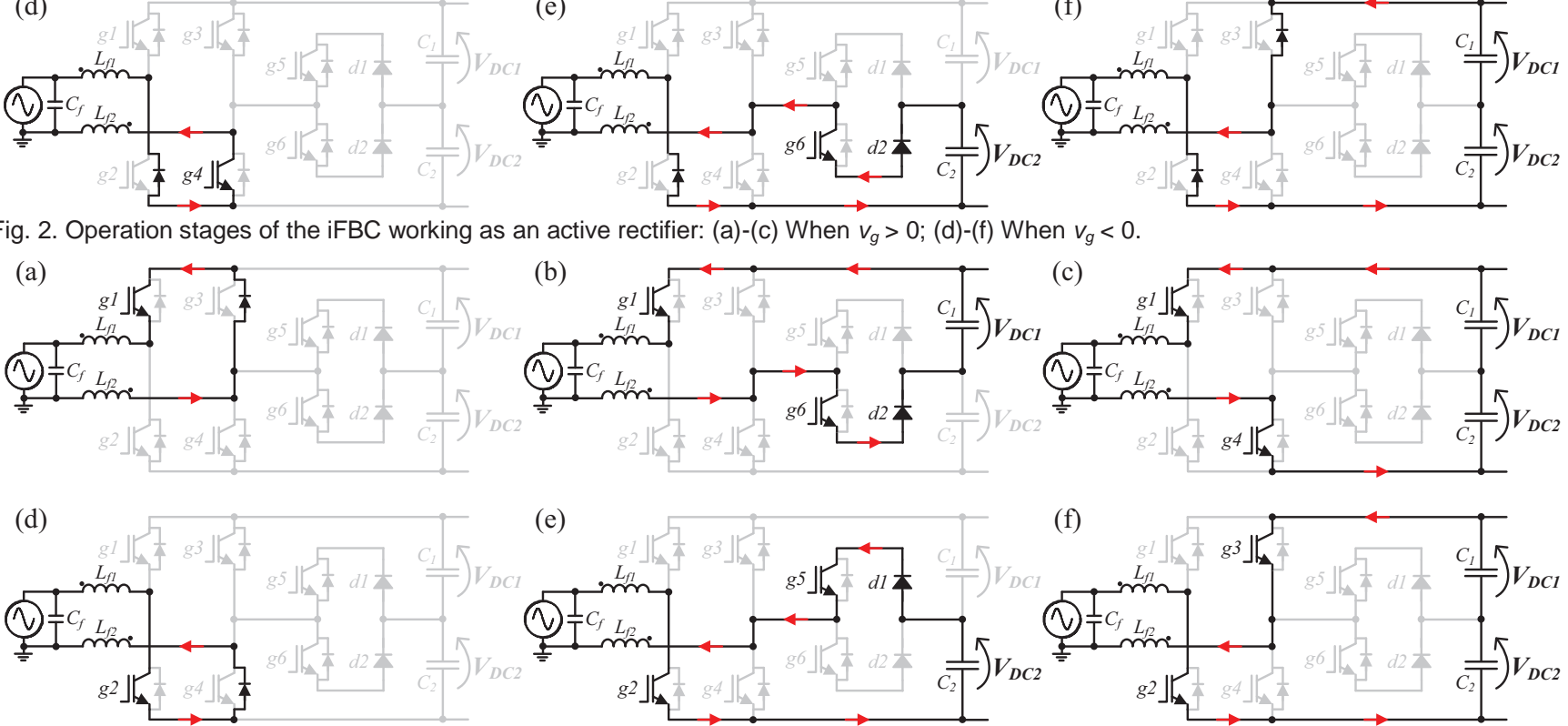

Fig. 3. Operation stages of the iFBC working as a grid-tie inverter: (a)-(c) When $v_{g}>0$; (d)-(f) When $v_{g}<0$.

\section{PRINCIPLE OF Operation OF THE IFBC}

This section presents the principle of operation of the $\mathrm{iFBC}$. It is described in detail when the IGBTs are on (1) or off (0) during a specific sampling period, in accordance with the FCS-MPC. The different states of the iFBC operating as an active rectifier or as a grid-tie inverter are summarized in Table I. Fig. 2 shows the equivalent circuits and the current paths when the iFBC is operating as an active rectifier. More specifically, Fig. 2(a)-(c) shows the current path when the power grid voltage is positive $\left(v_{g}>0\right)$, and Fig. $2(\mathrm{~d})$-(f) when is negative $\left(v_{g}<0\right)$. On the other hand, Fig. 3 shows the equivalent circuits and the current paths when the $\mathrm{iFBC}$ is operating as a grid-tie inverter. More specifically, Fig. 3(a)-(c) shows the current path when $v_{g}>0$, and Fig. 3(d)-(f) when $v_{g}<0$.

When the power grid voltage is positive $\left(v_{g}>0\right)$, the voltage produced by the iFBC $\left(v_{c v}\right)$ can assume three distinct values: $0,+V_{D C} / 2$ and $+V_{D C}$. On the other hand, when $v_{g}<0$, the voltage $v_{c v}$ can also assume three distinct values: $0,-V_{D C} / 2$ and $-V_{D C}$. Analyzing all these cases, it is possible to identify five different voltage levels and two forms for obtaining the level 0 (which is useful for dividing the losses between the IGBTs $g 1, g 2, g 3$ and $g 4$ ). Analyzing Table I, it is possible to observe that, using the $\mathrm{iFBC}$ as an active rectifier it is necessary to use four IGBTs ( $g 3$ and $g 5$ when $v_{g}>0$, and $g 4$ and $g 6$ when $v_{g}<0$ ), and using the iFBC as a grid-tie inverter it is necessary to use six IGBTs $\left(g l, g 3, g 4\right.$ and $g 6$ when $v_{g}>0$
TABLE I

POSSIBLE STATES OF THE IFBC

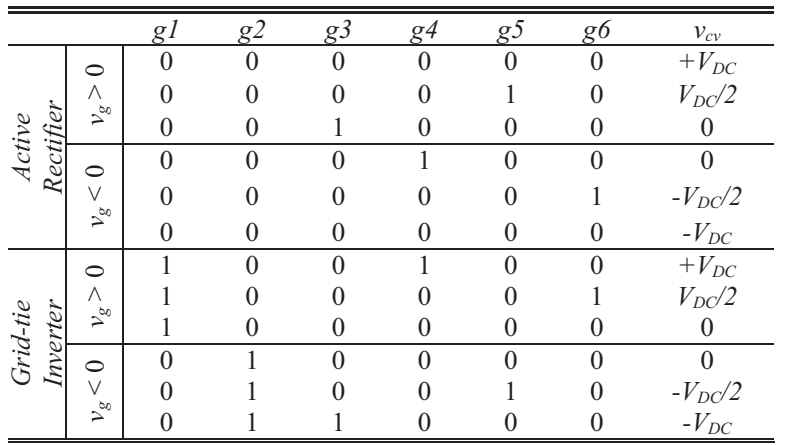

and $g 2, g 3, g 4$ and $g 5$ when $\left.v_{g}<0\right)$. In both operation modes, the maximum voltage in the IGBTs $g 1$ and $g 2$ is $V_{D C}$, and in the IGBTs $g 3, g 4, g 5$ and $g 6$ is $V_{D C} / 2$. The maximum voltage in the diodes $d 1$ and $d 2$ is also $V_{D C} / 2$.

Fig. 4 shows some simulation results, obtained with PSIM $\mathrm{v} 9.0$, of the $\mathrm{iFBC}$ during the operation as an active rectifier. Fig. 4(a) shows the power grid voltage $\left(v_{g}\right)$ and the grid current $\left(i_{g}\right)$. In this figure, it is possible to observe that the grid current is increasing without sudden variations. In this case, the rms value of the grid current increases from $9 \mathrm{~A}$ to $17 \mathrm{~A}$. Fig. 4(b) shows the grid current $\left(i_{g}\right)$ and its reference $\left(i_{g}{ }^{*}\right)$ in detail. This simulation result shows that the grid current $\left(i_{g}\right)$ tracks its reference $\left(i_{g}{ }^{*}\right)$ very well even with variable switching frequency. 

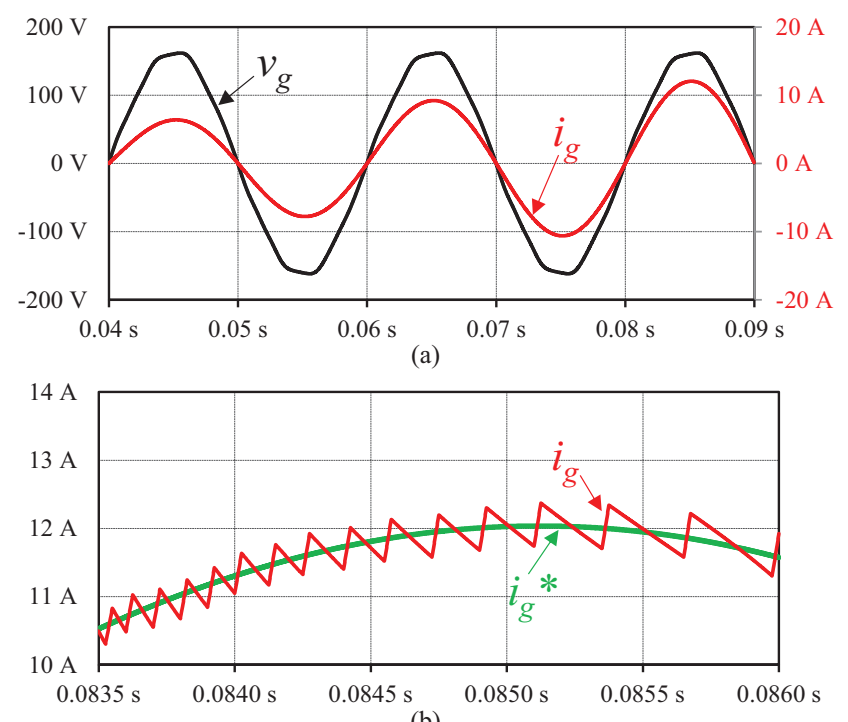

(b)

Fig. 4. Simulation results during the $\mathrm{FFBC}$ operation as an active rectifier: (a) Power grid voltage $\left(v_{g}\right)$; Grid current $\left(i_{g}\right)$; (b) Detail of the grid current $\left(i_{g}\right)$ and its reference $\left(i_{g}^{*}\right)$.

Fig. 5 shows some simulation results of the iFBC during the operation as a grid-tie inverter. Fig. 5(a) shows the power grid voltage $\left(v_{g}\right)$ and the grid current $\left(i_{g}\right)$. In this simulation result a dc-dc boost-type converter was used to interface a solar photovoltaic system, which is responsible for controlling the dc-link voltage and for defining the operation power value of the $\mathrm{iFBC}$. Due to the power variation, it is possible to observe that the injected grid current has sudden variations. In the first variation the instantaneous value of the reference current $\left(i_{g}{ }^{*}\right)$ changes from 1.4 A to 7.2 A, and in the second it changes from 7.2 A to 4.3 A. Fig. 5(b) shows in detail the grid current $\left(i_{g}\right)$ and its reference $\left(i_{g}{ }^{*}\right)$. This simulation result shows that the grid current $\left(i_{g}\right)$ tracks its reference $\left(i_{g}{ }^{*}\right)$ very well with a low time delay even with variable switching frequency. In the first sudden variation the measured time delay was $0.21 \mathrm{~ms}$ and in the second $0.13 \mathrm{~ms}$.

Fig. 6 shows some simulation results during the operation as an active rectifier. Fig. 6(a) shows the grid current $\left(i_{g}\right)$ with step changes in the load. In the first period it was used a load of $1000 \mathrm{~W}$, in the second period a load of $400 \mathrm{~W}$, in the third period a load of $800 \mathrm{~W}$, in the fourth period a load of $200 \mathrm{~W}$, and in the last period a load of $600 \mathrm{~W}$. In order to show the advantages of the $\mathrm{FBBC}$, it was also simulated the H-Bridge converter for the same conditions. Fig. 6(b) shows in detail the grid current $\left(i_{g}\right)$ using the $\mathrm{iFBC}$ and the $\mathrm{H}$-Bridge converter in comparison with the reference $\left(i_{g} *\right)$. As it can be seen, the grid current produced by the $\mathrm{iFBC}$ is more accurate than the current produced by the $\mathrm{H}$-Bridge converter. For the operation power values of $200 \mathrm{~W}, 400 \mathrm{~W}, 600 \mathrm{~W}, 800 \mathrm{~W}$ and $1000 \mathrm{~W}$ the rms error of the grid current using the iFBC was, respectively, $0.6 \%, 0.3 \%, 0.1 \%, 0.09 \%$, and $0.01 \%$. Using the $\mathrm{H}$-Bridge it was, respectively, $1.66 \%, 0.68 \%, 0.68 \%, 0.2 \%$, and $0.2 \%$. The measured THD of the grid current using the iFBC and the H-Bridge converter during the operation as an active rectifier and as grid-tie inverter for the aforementioned five periods is shown in Table II. The measured THD is lower
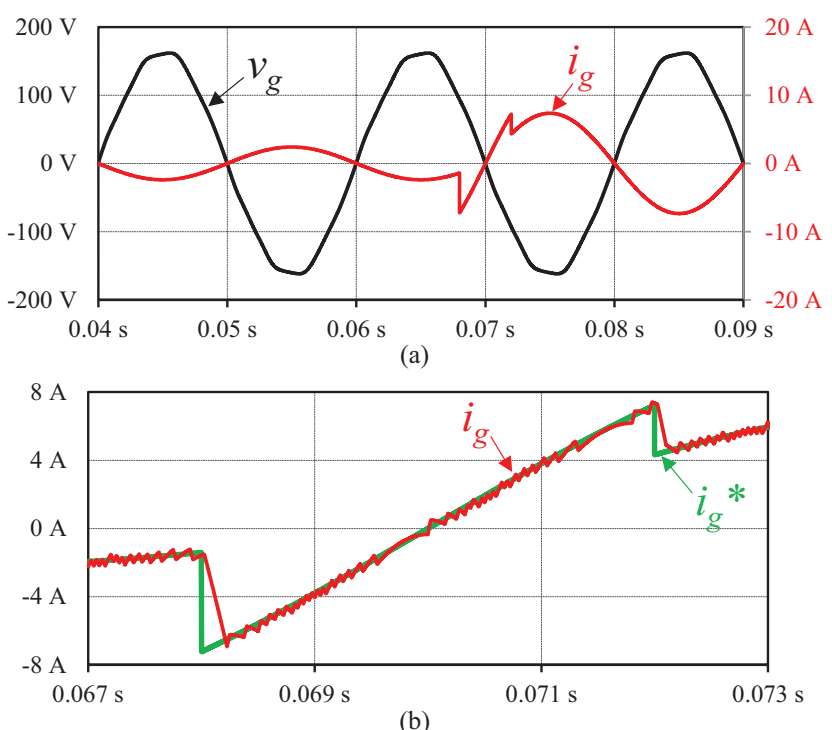

Fig. 5. Simulation results during the iFBC operation as a grid-tie inverter: (a) Power grid voltage $\left(v_{g}\right)$; Grid current $\left(i_{g}\right)$; (b) Detail of the grid current $\left(i_{g}\right)$ and its reference $\left(i_{g}^{*}\right)$.
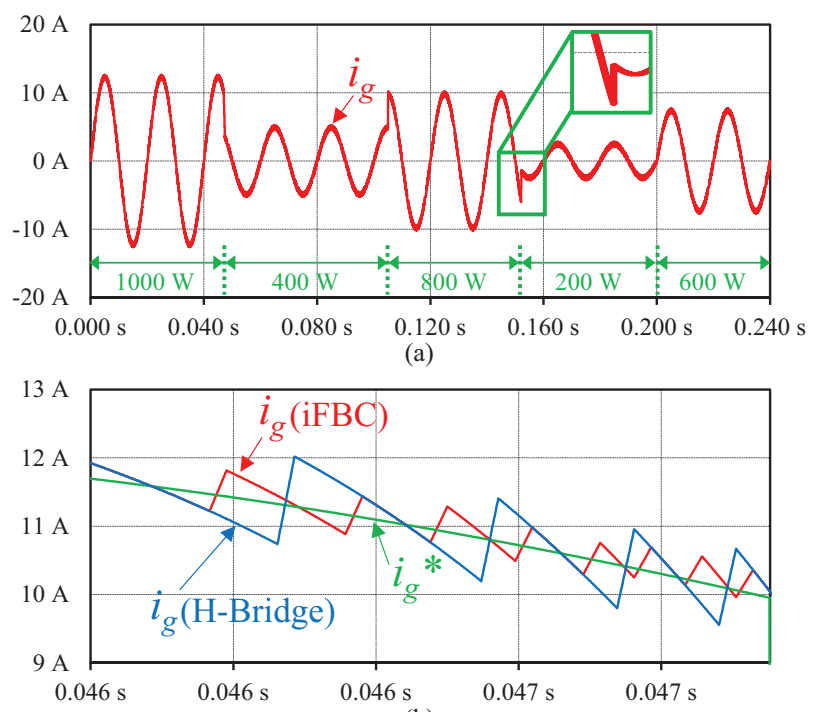

(b)

Fig. 6. Simulation results during the operation as an active rectifier: (a) Grid current $\left(i_{g}\right)$ with step changes in the load; (b) Detail of the current reference $\left(i_{g}^{*}\right)$ and the grid current $\left(i_{g}\right)$ using the iFBC and the H-Bridge converter.

TABLE ॥

THD COMPARISON BETWEEN THE iFBC AND THE H-BRIDGE CONVERTER

\begin{tabular}{c|c|c|c|c}
\hline \hline \multirow{2}{*}{ Power } & \multicolumn{2}{|c|}{ Active Rectifier } & \multicolumn{2}{c}{ Grid-Tie Inverter } \\
\cline { 2 - 5 } & iFBC & H-Bridge & iFBC & H-Bridge \\
\hline $200 \mathrm{~W}$ & $5.71 \%$ & $14.6 \%$ & $6.41 \%$ & $12.4 \%$ \\
$400 \mathrm{~W}$ & $2.87 \%$ & $7.04 \%$ & $3.62 \%$ & $6.39 \%$ \\
$600 \mathrm{~W}$ & $1.95 \%$ & $4.57 \%$ & $2.29 \%$ & $4.36 \%$ \\
$800 \mathrm{~W}$ & $1.49 \%$ & $3.33 \%$ & $1.86 \%$ & $3.46 \%$ \\
$1000 \mathrm{~W}$ & $1.48 \%$ & $2.72 \%$ & $1.48 \%$ & $2.64 \%$ \\
\hline \hline
\end{tabular}

using the iFBC for all the operation power values, and for both operation modes, as an active rectifier or as a grid-tie inverter.

\section{MOdEl Predictive CONTROL}

In this section the FCS-MPC applied to the $\mathrm{iFBC}$ is described in detail. It is important to refer that this analysis is 
valid for the $\mathrm{iFBC}$ in both operation modes, i.e., operating as an active rectifier or as a grid-tie inverter. During the operation as an active rectifier the iFBC is used to control the grid current and the dc-link voltage, i.e., a power theory is necessary in order to obtain the instantaneous value of the grid current reference. On the other hand, when the iFBC is used as a grid-tie inverter, the value of the grid current reference is provided to the digital control, e.g., from a dc-dc back-end converter used to interface renewable energy sources. In this operation mode the dc-link voltage is controlled by the dc-dc back-end converter and, therefore, it is not necessary to use the power theory for obtaining the grid current reference. In terms of the FCS-MPC, the main difference between both operation modes is the selection of the gate pulse patterns.

\section{A. Power Theory}

The power theory is used for obtaining the grid current reference $\left(i_{g}{ }^{*}\right)$, i.e., a signal that is directly proportional to the power grid voltage $\left(v_{g}\right)$ to maintain an unitary power factor [43][44]. The Fryze-Buchholz-Depenbrock (FBD) method, proposed in [45], consists in considering the power converter as an conductance from the power grid point of view. Therefore, it can be established:

$$
i_{g}{ }^{*}=G v_{g}
$$

where, $G$ denotes a conductance that represents the iFBC. Using the rms values of the power grid voltage $\left(V_{G}\right)$ and the grid current $\left(I_{G}\right)$, the conductance $G$ can be defined by:

$$
G=\frac{I_{G}}{V_{G}} \text {. }
$$

Taking into account that the grid current $\left(i_{g}\right)$ is in phase (operation as an active rectifier), or in phase opposition (operation as a grid-tie inverter), with the power grid voltage $\left(v_{g}\right),(2)$ can be rewritten in terms of active power $\left(P_{G}\right)$ :

$$
G=\frac{P_{G}}{V_{G}^{2}} .
$$

Neglecting the losses, this active power corresponds to the power in the dc side $\left(P_{D C}\right)$ and the power $\left(P_{C}\right)$ to maintain the dc-link voltage controlled. Substituting (3) in (1), the grid current reference $\left(i_{g}{ }^{*}\right)$ is defined by:

$$
i_{g}^{*}=\frac{P_{G}}{V_{G}{ }^{2}} v_{g} .
$$

The reference current determined by (4) changes according to the operation power value $\left(P_{G}\right)$. Therefore, the reference current is dynamically adjusted according to the operation mode. Analyzing (4), it is possible to infer that the waveform of the grid current reference $\left(i_{g}{ }^{*}\right)$ is directly influenced by the waveform of the power grid voltage $\left(v_{g}\right)$. Taking into account that the power grid voltage can have harmonic content, a phase-locked loop algorithm is used in order to obtain a grid current reference proportional only to the fundamental component of the power grid voltage [46]. Therefore, the grid current reference is sinusoidal even when a distorted power grid voltage is present. The dc-link voltages $\left(V_{D C 1}\right.$ and $\left.V_{D C 2}\right)$ are controlled through a PI controller. These voltages are controlled to the same voltage $(85 \mathrm{~V}$ in each capacitor)

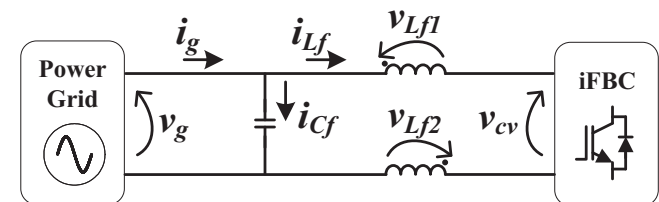

Fig. 7. Representation of the voltages and currents between the power grid and the iFBC.

independently of the iFBC operation power value.

\section{B. Predictive Model}

The predictive model is based on the circuit equations and is aimed to predict the grid current as a function of its actual and previous values. Analyzing the voltages and currents identified in Fig. 7, it can be established that:

$$
\begin{gathered}
v_{g}=v_{L f 1}+v_{L f 2}+v_{c v}, \\
i_{g}=i_{C f}+i_{L f 1} .
\end{gathered}
$$

From (6), substituting the current in the $C_{f}$ filter, (5) can be rewritten by:

$$
v_{g}=L_{f} \frac{d i_{g}}{d t}-L_{f} C_{f} \frac{d^{2} v_{g}}{d t^{2}}+v_{c v},
$$

where, $L_{f}=L_{f 1}+L_{f 2}$. Taking into account that a digital controller is used, the discrete implementation of (7) using the forward Euler method is:

$$
\begin{aligned}
& v_{g}[k]=L_{f} \frac{i_{g}[k+1]-i_{g}[k]}{T}+v_{c v}[k]- \\
& -L_{f} C_{f} \frac{v_{g}[k+1]-2 v_{g}[k]+v_{g}[k-1]}{T^{2}} .
\end{aligned}
$$

This method can be applicable to discretize (7) [29]. However, the backward Euler method can also be applied for the same purpose [30]. Rewriting (8) in terms of the predict current, i.e., the current in the instant $[k+1]$ is obtained:

$$
\begin{aligned}
& i_{g}[k+1]=i_{g}[k]+\frac{T}{L_{f}}\left(v_{g}[k]-v_{c v}[k]\right)+ \\
& +\frac{C_{f}}{T}\left(v_{g}[k+1]-2 v_{g}[k]+v_{g}[k-1]\right),
\end{aligned}
$$

where, the predicted power grid voltage in the $[k+1]$ can be obtained from [39]:

$$
v_{g}[k+1]=3 v_{g}[k]-3 v_{g}[k-1]+v_{g}[k-2] .
$$

Substituting (10) in (9) it is obtained the equation that allows to predict the grid current in the instant $[k+1]$.

\section{Cost Function}

After obtaining the grid current reference and the predicted grid current, the final stage consists in using a cost function for minimizing the grid current error, i.e., the difference between both. The grid current reference in the instant $[k+1]$ can be extrapolated from the previous samples with the same reasoning of (10). The cost function used in this paper is defined by:

$$
g[k+1]=\left|i_{g}{ }^{*}[k+1]-i_{g}[k+1]\right| .
$$

Taking into account that only one of the variables is controlled, no weighting factors are necessary for this cost 


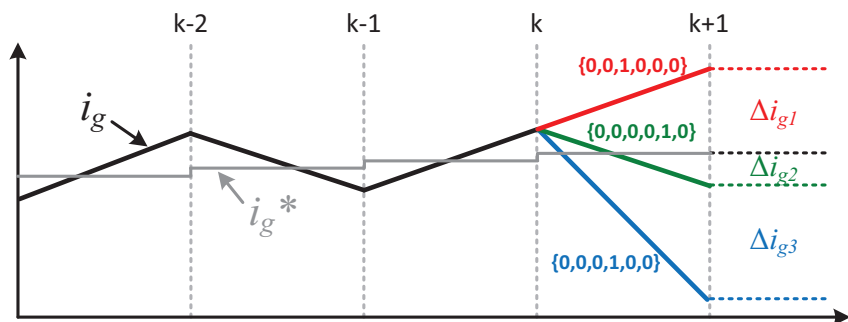

Fig. 8. Example of the state selection for minimizing the grid current error.

function, as well as no tuning processes. This type of cost function is very common when is required to control the grid current of voltage-source converters [47][39]. During each sampling period $(25 \mu \mathrm{s})$ the gate pulse patterns for the IGBTs are defined. Therefore, the state of the iFBC during such sampling period is defined in order to minimize the grid current error. The error is zero when the cost function is zero.

\section{Gate Pulses Patterns}

The gate pulses pattern is selected according to the iFBC operation mode (active rectifier or grid-tie inverter) and the result of the cost function. Fig. 8 shows a simulation result of an example of the state selection. In this situation the smallest error $\left(\Delta i_{g 2}\right)$ is obtained when the state of the iFBC defined by $\{0,0,0,0,1,0\}$ is selected. Therefore, during the time interval $[k, k+1]$ only the IGBT $g 5$ is on.

\section{Developed Prototype}

In this section the developed prototype of the $\mathrm{iFBC}$ is described in detail, i.e., the digital controller and the power converter.

\section{A. Digital Controller}

The digital controller is mainly based on the DSP TMS320F28335 from Texas Instruments, where the aforementioned FCS-MPC is implemented. The digital controller is also composed of a signal conditioning board to converter the analog voltages and currents for the digital values used in the DSP. In this board the ADC MAX1320 from MAXIM is used. The voltages are measured with sensors LV-25 P and the currents with sensors LA-55 P, both from LEM. The output signals from the DSP (gate pulse patterns) are adjusted to input signals of the gate driver through a command board. In this board a protection circuit is also included, and it consists in comparing the measured voltages and currents with the predefined references. The measured voltages and currents are acquired with a sampling frequency of $40 \mathrm{kHz}$. For such purpose it is used a timer programmed to obtain interruptions at $25 \mu \mathrm{s}$. Therefore, considering that in the maximum the states of the IGBTs will change from one interruption to another, then the maximum switching frequency is limited to $20 \mathrm{kHz}$. In the digital controller a digital-to-analog converter (DAC TLV5610 from Texas Instruments) is also used in order to visualize the digital values in an oscilloscope.

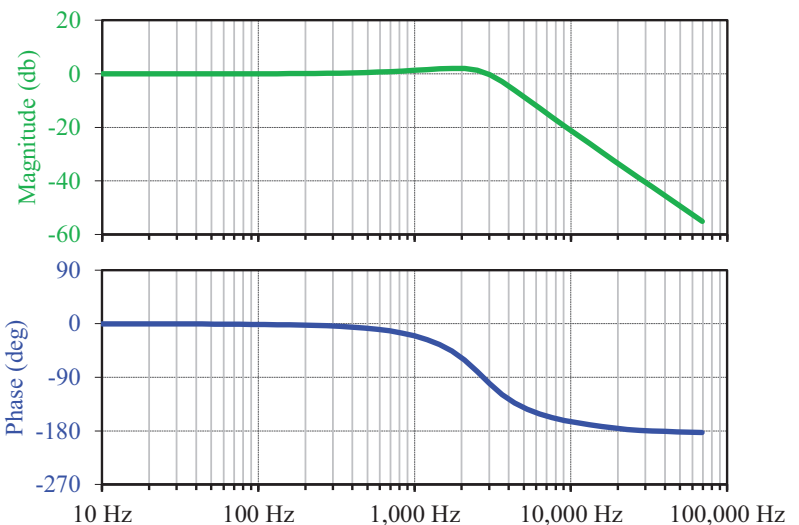

Fig. 9. Bode plot of the second-order low-pass $L_{f} C_{f}$ passive filer characteristic with passive damping.

\section{B. Power Converter}

The iFBC uses the IGBTs IXXR110N65B4H1 from IXYS and the diodes IR HFA15PB60 from International Rectifier. The dc-link is composed of ten capacitors, each one with a nominal value of $560 \mu \mathrm{F} / 450 \mathrm{~V}$. The gate drivers are composed of optocouplers HCPL3120 from Avago Technologies and isolated dc-dc sources NMV1515SC from Murata. The iFBC is connected to the power grid through a second-order low-pass $L_{f} C_{f}$ passive filter, which is composed of an inductor of $3 \mathrm{mH}$ and a capacitor of $3 \mu \mathrm{F}$.

The capacitor is split in two $(2 \mu \mathrm{F}$ and $1 \mu \mathrm{F})$ and it is used a damping resistor of $120 \Omega$ in series with the capacitor of $2 \mu \mathrm{F}$ in order to smooth the gain response of the passive filter at the cutoff frequency. The bode plot of this passive filter is shown in Fig. 9. The cutoff frequency of this filter is around $1.6 \mathrm{kHz}$.

In the inductor design, two cores T300-60D from MICROMETALS were used. Analyzing (9), it is possible to observe that the predicted current is influenced by the inductor value. Using a fixed value for the inductor, the control system can select a state for the iFBC that effectively does not correspond to the state that minimizes the error between the grid current and its reference. In order to contribute to the stability of the digital control system, instead of using a fixed value for the inductor, it is used the real value of the inductor in function of the grid current, described by:

$$
L=0.001\left(0.2 i_{g}{ }^{3}-7.5 i_{g}{ }^{2}-96.2 i_{g}\right)+7.59 \text {. }
$$

Therefore, the equation (12) is used in (9) in order to introduce the nonlinearity of the inductor in the FCS-MPC. Besides the effect of the inductor value variation, other criteria can be considered for the stability analysis. As example, the analysis of the stability and performance of the MPC applied to an active rectifier is presented in detail in [48].

\section{EXPERIMENTAL VALIDATION}

In this section the main experimental results obtained with the $\mathrm{iFBC}$ are presented. These results were acquired with a digital Yokogawa DL708E digital oscilloscope, with a Fluke 435 Power Quality Analyzer, and with a current probe Tektronix AM5031. The specifications of the experimental setup are shown in Table III. Table IV shows the time required 
TABLE III

SPECIFICATIONS OF THE EXPERIMENTAL SETUP

\begin{tabular}{ccc}
\hline \hline Parameters & Value & Unit \\
\hline Power Grid Voltage & 115 & $\mathrm{~V}$ \\
Grid Frequency & 50 & $\mathrm{~Hz}$ \\
Maximum Output Power & 1000 & $\mathrm{~W}$ \\
Dc-link Voltage & 170 & $\mathrm{~V}$ \\
Total Power Factor @ Full Load & 0.99 & - \\
THDi\% @ Full Load & 1.4 & - \\
Sampling Frequency & 40 & $\mathrm{kHz}$ \\
Maximum Switching Frequency & 20 & $\mathrm{kHz}$ \\
\hline \hline
\end{tabular}

TABLE IV

Time Required by the Main TASks of the Control Algorithm

\begin{tabular}{ccc}
\hline \hline Tasks & Value & Unit \\
\hline ADCs Reading & 690 & $\mathrm{~ns}$ \\
PLL Synchronization & 820 & $\mathrm{~ns}$ \\
Dc-link Voltages Digital Filtering & 1800 & $\mathrm{~ns}$ \\
Power Theory & 450 & $\mathrm{~ns}$ \\
Current Reference Prediction & 820 & $\mathrm{~ns}$ \\
Cost Function & 500 & $\mathrm{~ns}$ \\
Gate Pulses & 800 & $\mathrm{~ns}$ \\
\hline \hline
\end{tabular}

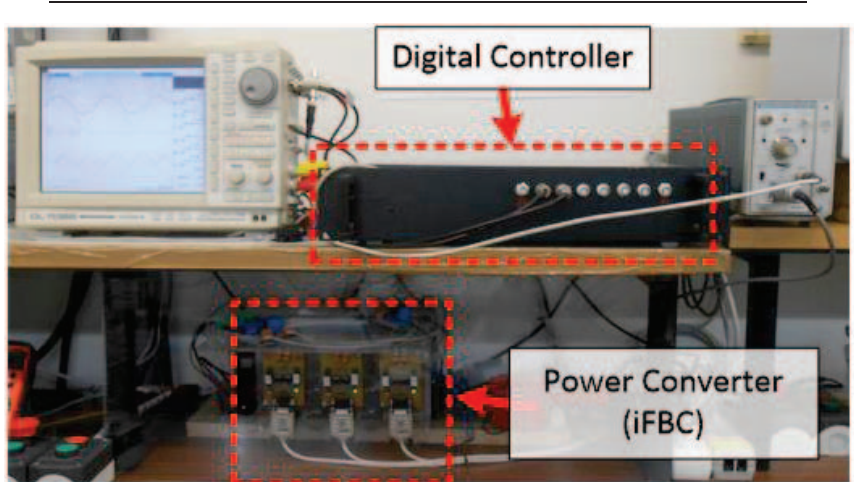

Fig. 10. Experimental setup used during the experimental validation of the iFBC controlled with FCS-MPC.

by the main tasks of the digital control algorithm. These times were measured using one of the features available in the Code Composer Studio from Texas Instruments. The experimental setup used during the experimental validation of the $\mathrm{iFBC}$ as an active rectifier and as a grid-tie inverter is shown in Fig. 10.

\section{A. iFBC Operating as an Active Rectifier}

In this item the experimental results of the iFBC operating as an active rectifier are presented. For such purpose the iFBC was connected to the power grid $(115 \mathrm{~V})$ and the dc-link voltage was controlled to a voltage of $170 \mathrm{~V}$, i.e., $85 \mathrm{~V}$ in each capacitor. Fig. 11 shows the grid current $\left(i_{g}\right)$, the power grid voltage $\left(v_{g}\right)$, and the voltage produced by the $\mathrm{iFBC}\left(v_{c v}\right)$ (i.e., the voltage between the $L_{f} C_{f}$ passive filter and the IGBTs leg) in detail. As it can be observed the grid current $\left(i_{g}\right)$ is in phase with the power grid voltage $\left(v_{g}\right)$, therefore the iFBC operates with a unitary power factor. It is important to note that these results are not exactly like the results shown in Fig. 8, because the observations were in different instants and in different contexts. Moreover, as it can be seen, the grid current does not follow exactly a simple ramp form due to the nonlinearity of the second-order low-pass $L_{f} C_{f}$ passive filter. In this specific case, i.e., during the transition from the positive to the negative semi-cycle, the minimum ripple in the grid current is

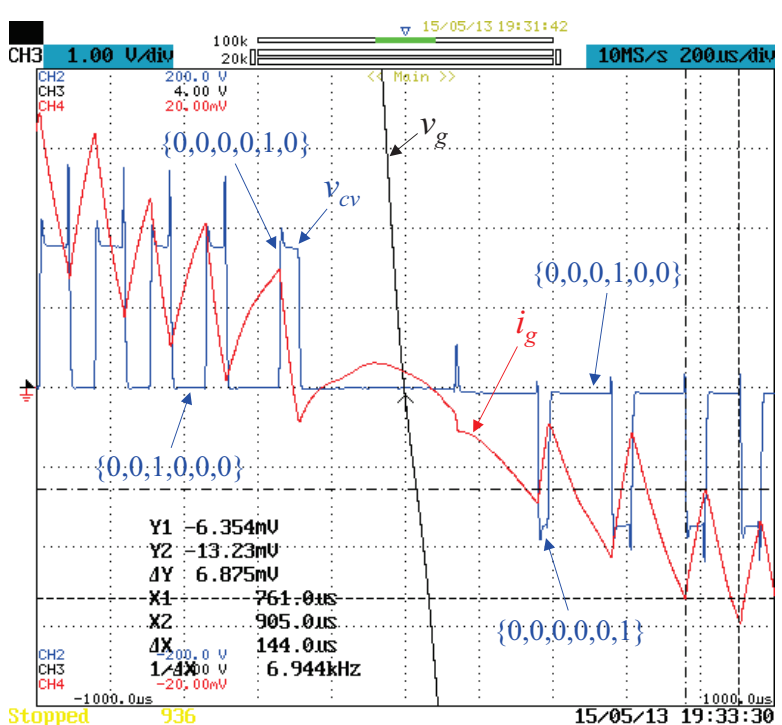

Fig. 11. Experimental results of the power grid voltage $\left(v_{g}: 1 \mathrm{~V} / \mathrm{div}\right)$, grid current $\left(i_{g}: 500 \mathrm{~mA} / \mathrm{div}\right)$ and voltage produced by the iFBC $\left(v_{c v}: 50 \mathrm{~V} /\right.$ div) operating as an active rectifier.

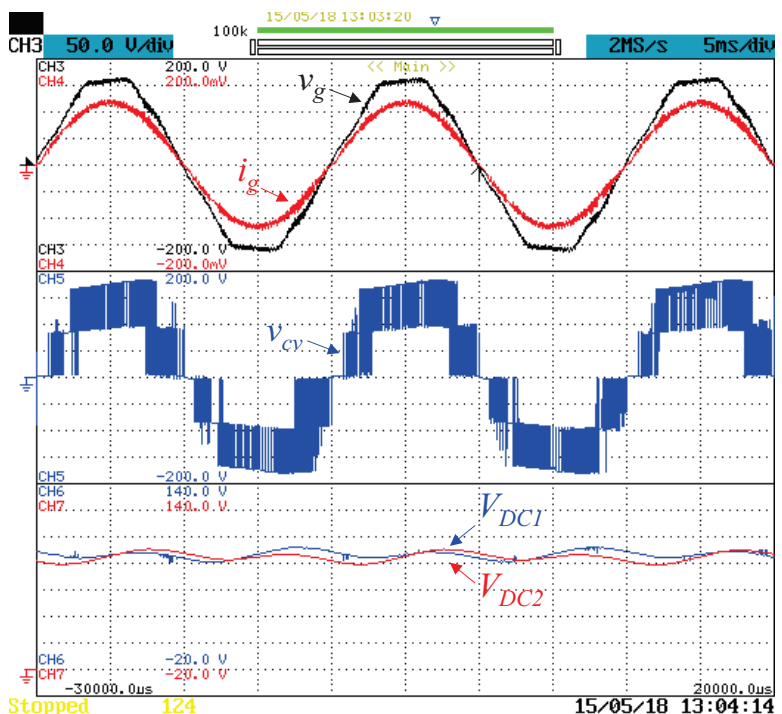

Fig. 12. Experimental results of the power grid voltage $\left(v_{g}: 50 \mathrm{~V} / \mathrm{div}\right)$, grid current $\left(i_{g}: 5 \mathrm{~A} / \mathrm{div}\right)$, voltage produced by the iFBC $\left(v_{c v}: 50 \mathrm{~V} / \mathrm{div}\right)$, and dc-link voltages ( $V_{D c}: 20 \mathrm{~V} /$ div) for operation as an active rectifier.

$688 \mathrm{~mA}$ and the switching frequency is $6.944 \mathrm{kHz}$ (about $35 \%$ of the maximum switching frequency). In Fig. 11 is possible to observe that when $v_{g}>0$, during the state $\{0,0,0,0,1,0\}$ the voltage $v_{c v}$ is $+V_{D C} / 2$, and during the state $\{0,0,1,0,0,0\}$, the voltage $v_{c v}$ is 0 . On the other hand, when $v_{g}<0$, during the state $\{0,0,0,0,0,1\}$ the voltage $v_{c v}$ is $-V_{D C} / 2$, and, during the state $\{0,0,0,1,0,0\}$, the voltage $v_{c v}$ is 0 . Fig. 12 shows in a detail of $50 \mathrm{~ms}$, the power grid voltage $\left(v_{g}\right)$, the grid current $\left(i_{g}\right)$, the voltage of the iFBC $\left(v_{c v}\right)$, and both dc-link voltages $\left(V_{D C 1}\right.$ and $\left.V_{D C 2}\right)$. In this experimental result it is possible to confirm that the grid current is sinusoidal even when the power grid voltage has harmonic content. It is also possible to confirm the five distinct voltages of the iFBC, i.e., $+V_{D C}$, $+V_{D C} / 2,0,-V_{D C} / 2$, and $-V_{D C}$. In this experimental result it is possible to observe that the dc-link voltages $\left(V_{D C 1}\right.$ and $\left.V_{D C 2}\right)$ are balanced with a maximum peak-to-peak voltage of $4.8 \mathrm{~V}$, 


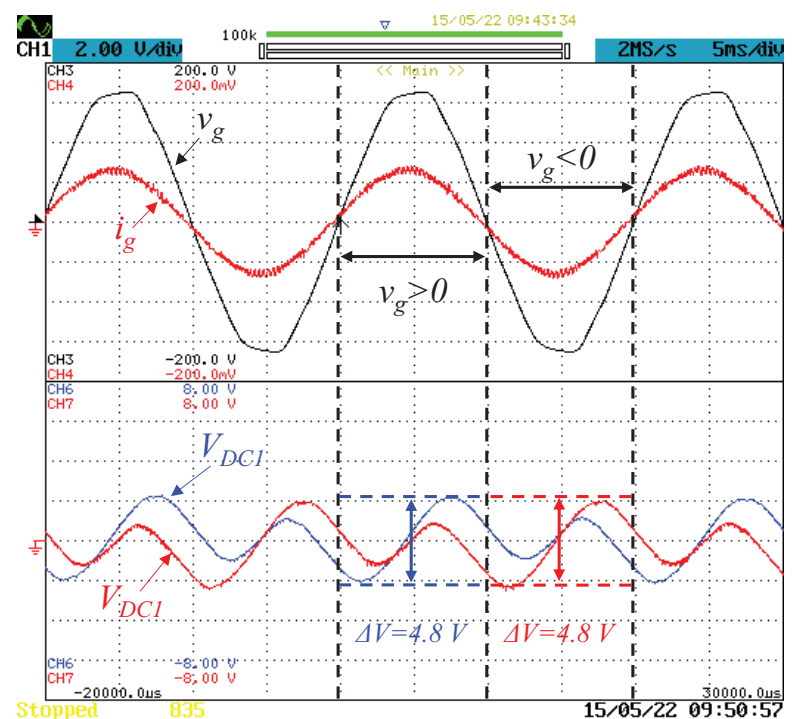

Fig. 13. Experimental results of the power grid voltage $\left(v_{g}: 50 \mathrm{~V} /\right.$ div $)$ and peak-to-peak voltages in the dc-link ( $\left.V_{D c}: 20 \mathrm{~V} / \mathrm{div}\right)$ for the ifBC operating as an active rectifier.

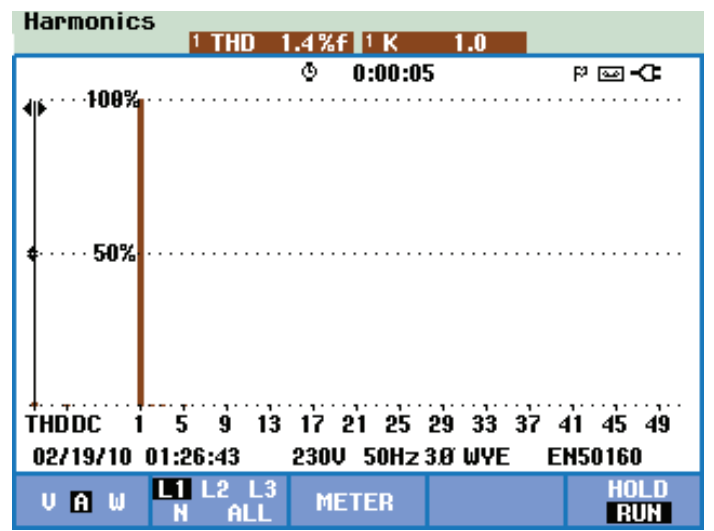

Fig. 14. Spectral analysis and THD\% of the grid current for a power of $980 \mathrm{~W}$ (grid current of $8.5 \mathrm{~A}$ ) with the iFBC operating as an active rectifier.

i.e., about $5 \%$ of the dc-link voltage in each capacitor. This relation can be improved increasing the capacitance of the dclink capacitors. If the dc-link voltages $\left(V_{D C 1}\right.$ and $\left.V_{D C 2}\right)$ are imbalance, then the voltage produced by the converter $\left(v_{c v}\right)$ will be directly influenced. It should be mentioned that the dc-link voltages are not used directly in the PI controller to obtain the grid current references, but its mean value. The dclink voltages $\left(V_{D C 1}\right.$ and $\left.V_{D C 2}\right)$ are acquired with a sampling frequency of $40 \mathrm{kHz}$ and then a digital filter is used to obtain the mean value of these voltages. Therefore, the influence of the peak-to-peak voltage is avoided to obtain the grid current reference.

Fig. 13 shows the power grid voltage and the peak-to-peak voltage in each dc-link capacitor. The voltage in each capacitor is controlled independently according to the power grid voltage $\left(v_{g}\right)$. If the power grid voltage is positive, then the voltage $V_{D C l}$ is adjusted. If the power grid voltage is negative, then the voltage $V_{D C 2}$ is adjusted. Fig. 14 shows the spectral analysis and the THD\% (1.4\%) of the grid current for a power of $980 \mathrm{~W}$, i.e., for a grid current of 8.5 A. Fig. 15 shows the variation of the grid current $\left(i_{g}\right)$ as a function of the power grid

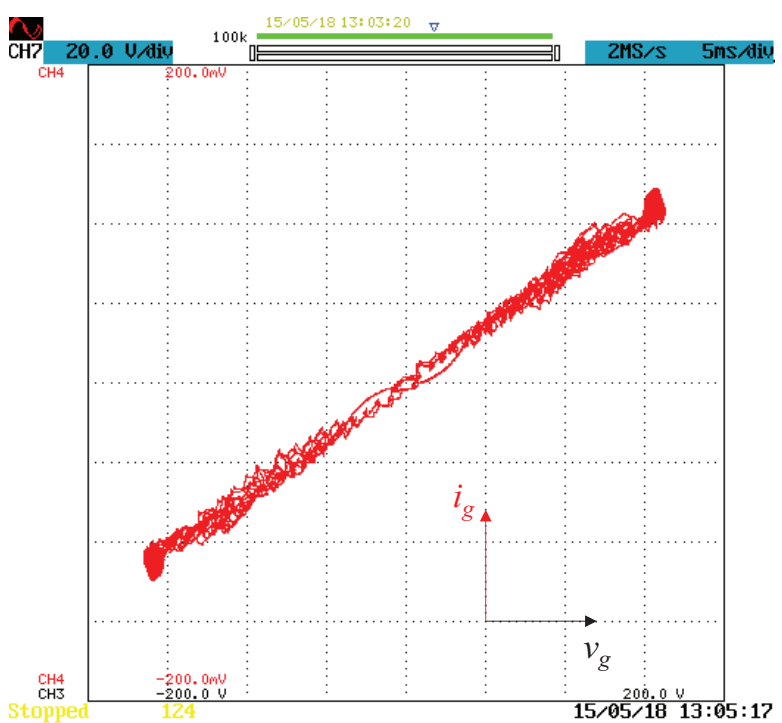

Fig. 15. Experimental result of the grid current ( $\left.i_{g}: 5 \mathrm{~A} / \mathrm{div}\right)$ and power grid voltage $\left(v_{g}: 50 \mathrm{~V} / \mathrm{div}\right)$ in $\mathrm{X}-\mathrm{Y}$ mode for the iFBC as an active rectifier.

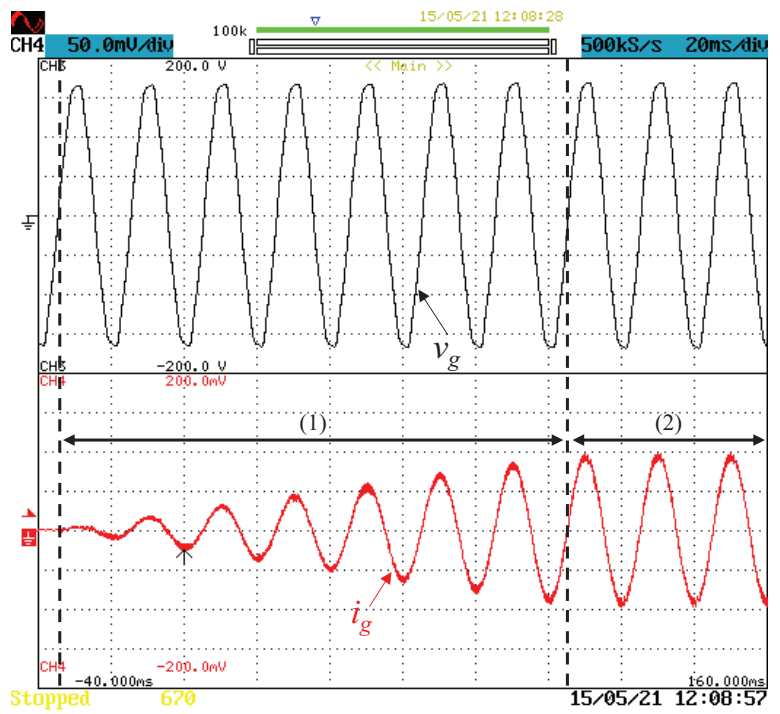

Fig. 16. Experimental results during transient of the power grid voltage $\left(v_{g}: 50 \mathrm{~V} / \mathrm{div}\right)$ and grid current $\left(i_{g}: 5 \mathrm{~A} / \mathrm{div}\right)$ for operation as an active rectifier.

current voltage $\left(v_{g}\right)$. As it can be seen, the grid current varies almost linearly with the power grid voltage. Due to the harmonic content of the power grid voltage $(\mathrm{THD}=2.4 \%)$, the variation is more critical during the maximum amplitude of the power grid voltage and the grid current. Fig. 16 shows the transient response of the grid current $\left(i_{g}\right)$, i.e., a variation from 0 A to 10 A during $0.14 \mathrm{~s}$ (a first stage (1) that corresponds to 7 cycles of the power grid voltage). In this situation, the iFBC increases the grid current $\left(i_{g}\right)$ without sudden variations in the current, which is favorable to the power quality maintenance. As it can be seen, the grid current $\left(i_{g}\right)$ is in phase with the power grid voltage $\left(v_{g}\right)$ during all the transient response.

During the operation as an active rectifier, the measured efficiency and the grid current THD\% for a range of operation from about $200 \mathrm{~W}$ to $1000 \mathrm{~W}$ are presented in Fig. 17(a) and Fig. 17(b), respectively. The maximum measured efficiency was $96.2 \%$ at $395 \mathrm{~W}$ and the minimum efficiency was $92.7 \%$ 

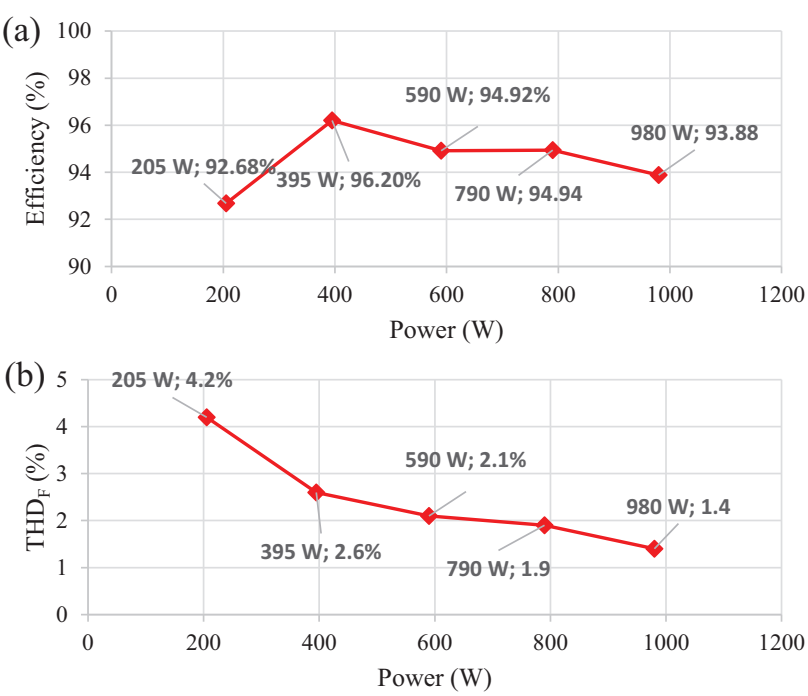

Fig. 17. Experimental results of $\mathrm{iFBC}$ for operation as an active rectifier: (a) Measured efficiency; (b) Measured grid current THD\%.

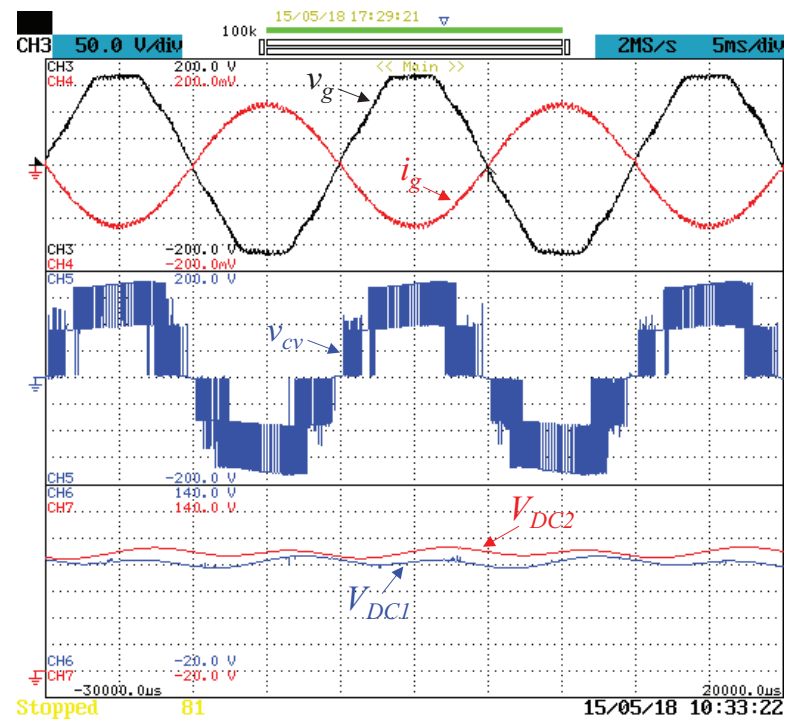

Fig. 18. Experimental results of the power grid voltage $\left(v_{g}: 50 \mathrm{~V} / \mathrm{div}\right)$, grid current ( $i_{g}: 5 \mathrm{~A} /$ div), voltage produced by the iFBC ( $v_{c v}: 50 \mathrm{~V} / \mathrm{div}$ ), and dc-link voltages ( $V_{D C}$ : $20 \mathrm{~V} / \mathrm{div}$ ) for operation as a grid-tie inverter.

at $205 \mathrm{~W}$. The efficiency of the $\mathrm{iFBC}$ as an active rectifier was measured using the aforementioned power quality analyzer and the current probe. For such purpose, the iFBC was connected to the power grid to a voltage of $115 \mathrm{~V}$, the dc-link voltage was controlled to a voltage of $170 \mathrm{~V}$, and a variable resistive load was used to change the $\mathrm{iFBC}$ operation power value. In terms of the grid current THD $\%$, the maximum value registered was $4.2 \%$ (at $205 \mathrm{~W}$ ) and the minimum was $1.4 \%$ (at $980 \mathrm{~W})$.

\section{B. iFBC Operating as a Grid-Tie Inverter}

In this item the experimental results of the iFBC operating as a grid-tie inverter are presented. For such purpose, the ac side of the iFBC was connected to the power grid $(115 \mathrm{~V})$ and the dc-link was connected to a dc voltage source of $170 \mathrm{~V}(85 \mathrm{~V}$ in each capacitor). Fig. 18 shows the grid current $\left(i_{g}\right)$, the power grid voltage $\left(v_{g}\right)$, and the voltage produced by the iFBC

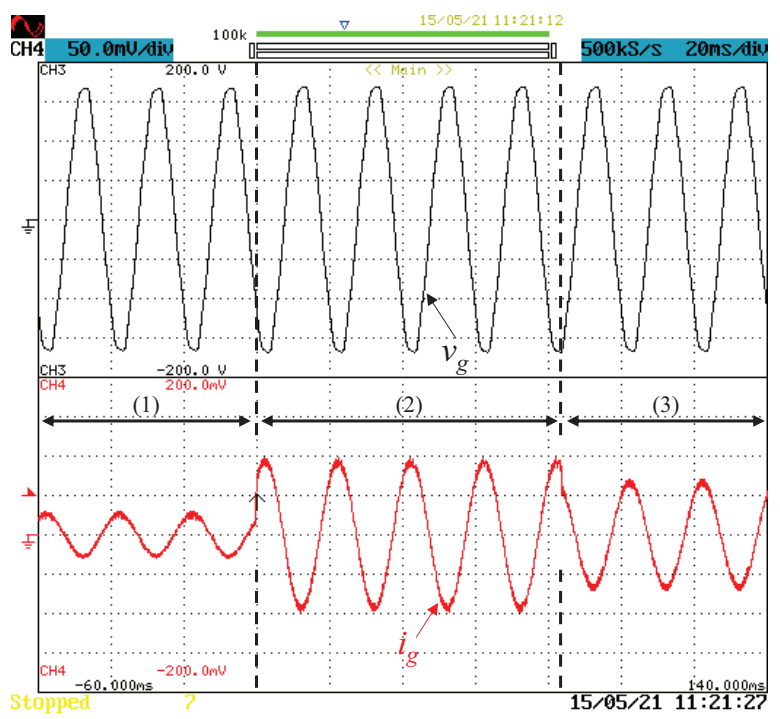

Fig. 19. Experimental results during transient of the power grid voltage ( $v_{g}: 50 \mathrm{~V} /$ div) and grid current $\left(i_{g}: 5 \mathrm{~A} /\right.$ div) for operation as a grid-tie inverter.
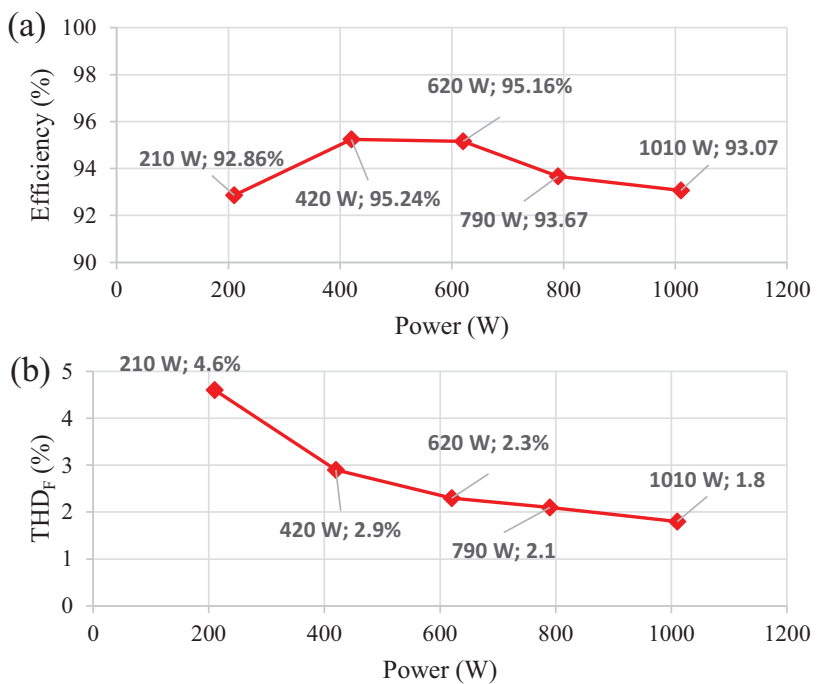

Fig. 20. Experimental results of iFBC during the operation as a grid-tie inverter: (a) Measured efficiency; (b) Measured grid current THD\%.

$\left(v_{c v}\right)$ in detail. In this operation mode, the grid current $\left(i_{g}\right)$ is in phase opposition with the power grid voltage $\left(v_{g}\right)$. Also in this operation mode it is possible to confirm that the grid current is sinusoidal even when the power grid voltage has harmonic content. It is also possible to confirm the five distinct voltages of the iFBC, i.e., $+V_{D C},+V_{D C} / 2,0,-V_{D C} / 2$, and $-V_{D C}$. Fig. 19 shows the transient response of the grid current $\left(i_{g}\right)$, i.e., from the first to the second stage it corresponds to a variation from $3 \mathrm{~A}$ to $10 \mathrm{~A}$ and from the second to the third stage to a variation from $10 \mathrm{~A}$ to $7 \mathrm{~A}$. In this situation, the grid current $\left(i_{g}\right)$ changes instantaneously between the stages. As it can be seen, the grid current $\left(i_{g}\right)$ is in phase opposition with the power grid voltage $\left(v_{g}\right)$ in both stages. During the operation as a grid-tie inverter, the measured efficiency and the grid current THD $\%$ for a range of operation from about $200 \mathrm{~W}$ to $1000 \mathrm{~W}$ are presented in Fig. 20(a) and Fig. 20(b), respectively. In this operation mode, the maximum measured efficiency was $95.2 \%$ at $420 \mathrm{~W}$ and the minimum efficiency was $92.9 \%$ at 
$210 \mathrm{~W}$. The efficiency of the $\mathrm{iFBC}$ as a grid-tie inverter was measured using the same aforementioned description. The iFBC was connected to the power grid to a voltage of $115 \mathrm{~V}$, the dc-link voltage was controlled to a voltage of $170 \mathrm{~V}$, and a variable power reference was used to change the iFBC operation power value. In terms of the grid current $\mathrm{THD} \%$, the maximum value registered was $4.6 \%$ (at $210 \mathrm{~W}$ ) and the minimum was $1.8 \%$ (at $1010 \mathrm{~W}$ ).

\section{CONCLUSION}

This paper presents an improved five-level bidirectional converter (iFBC) controlled by finite control set model predictive control (FCS-MPC). The paper presents in detail the iFBC hardware, the principle of operation, the power theory used for obtaining the grid current reference, the FCS-MPC, and the cost function for minimizing the error between the grid current and its reference. The experimental results, in steady-state and during transient operation, were obtained with the $\mathrm{iFBC}$ connected to the power grid and operating both as an active rectifier and as a grid-tie inverter. For both operation modes the efficiency and the THD\% were verified for different operation power values. The experimental results confirm that the FCS-MPC can be applied with success (in terms of efficiency, low grid current THD and controlled output voltage) to the iFBC.

\section{REFERENCES}

[1] Bhim Singh, Brij N. Singh, Ambrish Chandra, Kamal Al-Haddad, Ashish Pandey, Dwarka P. Kothari, "A Review of Single-Phase Improved Power Quality AC-DC Converters," IEEE Trans. Ind. Electron., vol.50, no.5, pp.962-981, Oct. 2003.

[2] Oscar García, José A. Cobos, Roberto Prieto, Pedro Alou, Javier Uceda, "Single Phase Power Factor Correction: A Survey," IEEE Trans. Power Electron., vol.18, no.3, pp.749-755, May 2003.

[3] Fernando Beltrame, Leandro Roggia, Luciano Schuch, José Renes Pinheiro, "A Comparison of High Power Single-Phase Power Factor Correction Pre-Regulators," IEEE ICIT Industrial Technology, pp.625630, Mar. 2010.

[4] Mehdi Narimani, Gerry Moschopoulos, "A New Single-Phase SingleStage Three-Level Power-Factor-Correction AC-DC Converter With Phase-Shift Modulation," IEEE Trans. Ind. Electron., vol.60, no.9, pp.3731-3735, Sept. 2013.

[5] Xueshan Liu, Jianping $\mathrm{Xu}$, Zhangyong Chen, Nan Wang, "SingleInductor Dual-Output Buck-Boost Power Factor Correction Converter," IEEE Trans. Ind. Electron., vol.62, no.2, pp.943-952, Feb. 2015 .

[6] Xiaogao Xie, Chen Zhao, Qiang Lu, Shirong Liu, “A Novel Integrated Buck-Flyback Nonisolated PFC Converter With High Power Factor,' IEEE Trans. Ind. Electron., vol.60, no.12, pp.5603-5612, Dec. 2013.

[7] André De Bastiani Lange, Thiago Batista Soeiro, Márcio Silveira Ortmann, Marcelo Lobo Heldwein, "Three-Level Single-Phase Bridgeless PFC Rectifiers," IEEE Trans. Power Electron., vol.30, no.6, pp.2935-2949, June 2015

[8] Laszlo Huber, Yungtaek Jang, Milan Jovanovic, "Performance Evaluation of Bridgeless PFC Boost Rectifier," IEEE Trans. Power Electron., vol.23, no.3, pp.1381-1390, May 2008.

[9] Roberto Martinez, Prasad N. Enjeti, "A High-Performance Singlephase Rectifier with Input Power Factor Correction," IEEE Trans. Power Electron., vol.11, no.2, pp.311-317, Mar. 1996.

[10] Jee-Woo Lim, Bong-Hwan Kwon, "A Power-Factor Controller for Single-Phase PWM Rectifiers," IEEE Trans. Ind. Electron., vol.46, no.5, pp.1035-1037, Oct. 1999.

[11] Serkan Dusmez, Shamim Choudhury, Manish Bhardwaj, Bilal Akin, "A Modified Dual-Output Interleaved PFC Converter Using Single
Negative Rail Current Sense for Server Power Systems," IEEE Trans. Power Electron., vol.29, no.10, pp.5116-5123, Oct. 2014.

[12] Mehdi Narimani, Gerry Moschopoulos, "A Novel Single-Stage Multilevel Type Full-Bridge Converter," IEEE Trans. Ind. Electron., vol.60, no.1, pp.31-42, Jan. 2013.

[13] José Rodríguez, Jih-Sheng Lai, Fang Zheng Peng, "Multilevel Inverters: A Survey of Topologies, Controls, and Applications," IEEE Trans. Ind. Electron., vol.49, no.4, pp.724-738, Aug. 2002.

[14] Jih-Sheng Lai, Fang Zheng Peng, "Multilevel Converters-A New Breed of Power Converters," IEEE Trans. Ind. Appl., vol.32, no.3, pp.509517, May 1996.

[15] Gabriel H. P. Ooi, Ali I. Maswood, Ziyou Lim, "Five-Level MultiplePole PWM AC-AC ConvertersWith Reduced Components Count," IEEE Trans. Ind. Electron., vol.62, no.8, pp.4739-4748, Aug. 2015.

[16] Rasoul Shalchi Alishah, Daryoosh Nazarpour, Seyed Hossei Hosseini, Mehran Sabahi, "Novel Topologies for Symmetric, Asymmetric, and Cascade Switched-Diode Multilevel Converter With Minimum Number of Power Electronic Components," IEEE Trans. Ind. Electron., vol. 61, no.10, pp.5300-5310, Oct. 2014.

[17] Concettina Buccella, Carlo Cecati, Maria Gabriella Cimoroni, Kaveh Razi, "Analytical Method for Pattern Generation in Five-Level Cascaded H-Bridge Inverter Using Selective Harmonic Elimination," IEEE Trans. Ind. Electron., vol.61, no.11, pp.5811-5819, Nov. 2014.

[18] Martina Calais, Lawrence J. Borle, Vassilios G. Agelidis, "Analysis of Multicarrier PWM Methods for a Single-Phase Five Level Inverter," IEEE PESC Power Electronics Specialists Conference, vol.3, pp.13511356, June 2001.

[19] Carlos Alberto Teixeira, Donald Grahame Holmes, Brendan P. McGrath, "Single-Phase Semi-Bridge Five-Level Flying-Capacitor Rectifier," IEEE Trans. Ind. Appl., vol.49, no.5, pp.2158-2166, Sept. 2013.

[20] P. Roshankumar, P. P. Rajeevan, K. Mathew, K. Gopakumar, Jose I. Leon, Leopoldo G. Franquelo, "A Five-Level Inverter Topology with Single-DC Supply by Cascading a Flying Capacitor Inverter and an HBridge," IEEE Trans. Power Electron., vol.27, no.8, pp.3505-3512, Aug. 2012.

[21] Yun Zhang, Li Sun, "An Efficient Control Strategy for a Five-Level Inverter Comprising Flying-Capacitor Asymmetric H-Bridge," IEEE Trans. Ind. Electron., vol.58, no.9, pp.4000-4009, Sept. 2011.

[22] S. Camur, B. Arifoglu, E. Kandemir Beser, E. Beser, "A Novel Topology for Single-Phase Five-Level Inverter Compared with $\mathrm{H}$ Bridge Inverter," SPEEDAM International Symposium on Power Electronics, Electrical Drives, Automation and Motion, pp.556-560, May 2006.

[23] Krishna Kumar Gupta, Shailendra Jain, "A NovelMultilevel Inverter Based on Switched DC Sources," IEEE Trans. Ind. Electron., vol.61, no.7, pp.3269-3278, July 2014.

[24] Hani Vahedi, Philippe-Alexandre Labbé, Hadi Y. Kanaan, Handy Fortin Blanchette, Kamal Al-Haddad, "A New Five-Level Buck-Boost Active Rectifier," IEEE ICIT International Conference on Industrial Technology, pp.2559-2564, Mar. 2015.

[25] Madhukar Rao. A, K. Sivakumar, "A Fault-Tolerant Single-Phase FiveLevel Inverter for Grid-Independent PV Systems," IEEE Trans. Ind. Electron., vol.62, no.12, pp.7569-7577, Dec. 2015.

[26] Sung-Jun Park, Feel-Soon Kang, Man Hyung Lee, Cheul-U Kim, “A New Single-Phase Five-Level PWM Inverter Employing a Deadbeat Control Scheme," IEEE Trans. Power Electron., vol.18, no.3, pp.831843, May 2003.

[27] Leonardo Augusto Serpa, "Current Control Strategies for Multilevel Grid Connected Inverters," $P h D$ Thesis, Swiss Federal Institute of Technology, Zurich, 2007.

[28] Marian P. Kazmierkowski, Luigi Malesani, "Current Control Techniques for Three-Phase Voltage-Source PWM Converters: A Survey," IEEE Trans. Ind. Electron., vol.45, no.5, pp.691-703, Oct. 1998.

[29] Patricio Cortés, Marian P. Kazmierkowski, Ralph M. Kennel, Daniel E. Quevedo, José Rodríguez, "Predictive Control in Power Electronics and Drives," IEEE Trans. Ind. Electron., vol.55, no.12, pp.4312-4324, Dec. 2008.

[30] Venkata Yaramasu, Marco Rivera, Bin Wu, Jose Rodriguez, "Model Predictive Current Control of Two-Level Four-Leg Inverters-Part I: Concept, Algorithm, and Simulation Analysis," IEEE Trans. Power Electron., vol.28, no.7, pp.3459-3468, July 2013. 
[31] Marco Rivera, Venkata Yaramasu, Jose Rodriguez, Bin Wu, "Model Predictive Current Control of Two-Level Four-Leg Inverters-Part II: Experimental Implementation and Validation," IEEE Trans. Power Electron., vol.28, no.7, pp.3469-3478, July 2013.

[32] Samir Kouro, Patricio Cortés, René Vargas, Ulrich Ammann, José Rodríguez, "Model Predictive Control - A Simple and Powerful Method to Control Power Converters," IEEE Trans. Ind. Electron., vol.56, no.6, pp.1826-1838, June 2009.

[33] Jose Rodriguez, Marian P. Kazmierkowski, José R.Espinoza, Pericle Zanchetta, Haitham Abu-Rub, Héctor A. Young, Christian A. Rojas, "State of the Art of Finite Control Set Model Predictive Control in Power Electronics," IEEE Trans. Ind. Informat., vol.9, no.2, pp.10031016, May 2013.

[34] Patricio Cortes, Jose Rodriguez, Cesar Silva, Alexis Flores, "Delay Compensation inModel Predictive Current Control of a Three-Phase Inverter," IEEE Trans. Ind. Electron., vol.59, no.2, pp.1323-1325, Feb. 2012.

[35] Muslem Uddin, Saad Mekhilef, Mutsuo Nakaoka, Marco Rivera, "Model Predictive Control of Induction Motor with Delay Time Compensation: An Experimental Assessment," IEEE APEC Applied Power Electronics Conference and Exposition, pp.543-548, Mar. 2015.

[36] James Scoltock, Tobias Geyer, Udaya K. Madawala, "Model Predictive Direct Power Control for Grid-Connected NPC Converters," IEEE Trans. Ind. Electron., vol.62, no.9, pp.5319-5328, Sept. 2015

[37] Md. Parvez Akter, Saad Mekhilef, Nadia Mei Lin Tan, Hirofumi Akagi, "Modified Model Predictive Control of a Bidirectional AC-DC Converter Based on Lyapunov Function for Energy Storage Systems," IEEE Trans. Ind. Electron., vol.63, no.2, pp.704-715, Feb. 2016.

[38] Dae-Keun Choi, Kyo-Beum Lee, "Dynamic Performance Improvement of AC/DC Converter Using Model Predictive Direct Power ControlWith Finite Control Set," IEEE Trans. Ind. Electron., vol.62, no.1, pp.757-767, Feb. 2015

[39] José Rodríguez, Jorge Pontt, César A. Silva, Pablo Correa, Pablo Lezana, Patricio Cortés, Ulrich Ammann, "Predictive Current Control of a Voltage Source Inverter," IEEE Trans. Ind. Electron., vol.54, no.1, pp.495-503, Feb. 2007.

[40] P. Zavala, M. Rivera, S. Kouro, J. Rodriguez, B. Wu, V. Yaramasu, C. Baier, J. Munoz, J. Espinoza, P. Melin, "Predictive Control of a Current Source Rectifier with Imposed Sinusoidal Input Currents," IEEE IECON Industrial Electronics Society, Vienna Austria, pp. 5842-5847, Nov. 2013

[41] Patricio Cortés, Gabriel Ortiz, Juan I. Yuz, José Rodríguez, Sergio Vazquez, Leopoldo G. Franquelo, "Model Predictive Control of an Inverter With Output LC Filter for UPS Applications," IEEE Trans. Ind. Electron., vol.56, no.6, pp.1875-1883, June 2009.

[42] Pericle Zanchetta, Patricio Cortes, Marcelo Perez, Jose Rodriguez, Cesar Silva, "Finite States Model Predictive Control for Shunt Active Filters," IEEE IECON Industrial Electronics Conference, pp.581-586, Nov. 2011.

[43] Frede Blaabjerg, Remus Teodorescu, Marco Liserre, Adrian V. Timbus, "Overview of Control and Grid Synchronization for Distributed Power Generation Systems," IEEE Trans. Ind. Electron., vol.53, no.5, pp.1398-1409, Oct. 2006

[44] Andrés A. Valdez-Fernández, Pánfilo R. Martínez-Rodríguez, Gerardo Escobar, Cesar A. Limones-Pozos, José M. Sosa, "A Model-Based Controller for the Cascade H-Bridge Multilevel Converter Used as a Shunt Active Filter," IEEE Trans. Ind. Electron., vol.60, no.11, pp.5019-5028, Nov. 2013.

[45] M. Depenbrock, "The FBD-Method, a Generally Applicable Tool for Analyzing Power Relations," IEEE Trans. Power Syst., vol.8, no.2, pp.381-387, May 1993

[46] Masoud Karimi-Ghartemani, "Linear and Pseudolinear Enhanced Phased-Locked Loop (EPLL) Structures," IEEE Trans. Ind. Electron., vol.61, no.3, pp.1464-1474, Mar. 2014.

[47] Luca Tarisciotti, Pericle Zanchetta, Alan Watson, Stefano Bifaretti, Jon C. Clare, "Modulated Model Predictive Control for a Seven-Level Cascaded H-Bridge Back-to-Back Converter," IEEE Trans. Ind. Electron., vol.61, no.10, pp.5375-5383, Oct. 2014

[48] Md. Parvez Akter, Saad Mekhilef, Nadia Mei Lin Tan, Hirofumi Akagi, "Stability and Performance Investigations of Model Predictive Controlled Active-Front-End (AFE) Rectifiers for Energy Storage

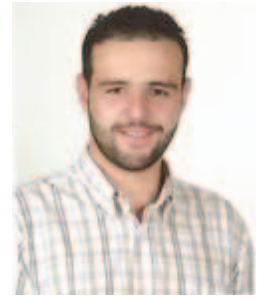

Systems," Journal of Power Electronics, vol.15, no.1, pp.202-215, Jan. 2015.

Vítor Monteiro (S'10) was born in Guimarães, Portugal, on May 1984. He received the M.Sc. in Industrial Electronics and Computers Engineering, from the School of Engineering of the University of Minho, in 2012. Since 2008 he is a member of the Group of Energy and Power Electronics (GEPE) of the Centro Algoritmi, at the University of Minho. Currently he is a PhD student supported by the doctoral scholarship SFRH/BD/80155/2011 granted by the Portuguese FCT agency, and a collaborator of the Centro Algoritmi of the University of Minho. His research interests are related with Power Electronics Converters, Digital Control Techniques, Smart Grids, and Electric Vehicles. Vítor is a student member of IEEE, member of the Industrial Electronics Society, and member of the Vehicular

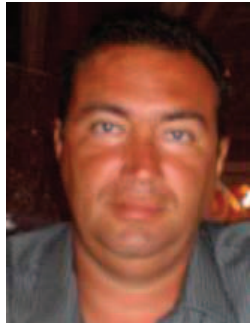
Technology Society.

João C. Ferreira (M'01, SM'15) is Professor at the ISCTE - Instituto Universitário de Lisboa and Consultant with different companies and institutions. He graduated in Physics at the Technical University of Lisbon (UTL/IST), Portugal, received an MSC in Telecommunication and a PhD degree in Computer Science Engineering from UTL/IST. $\mathrm{His}$ professional and research interests are in retrieval, geographic and multimedia retrieval, Electric Vehicle, Intelligent Systems, intelligent transportation (ITS) and sustainable mobility systems. He is the author of over 140 scientific papers of

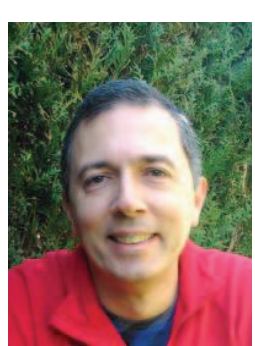
international conferences and workshops in different areas of computer science.

Andrés A. Nogueiras Meléndez (M'99, SM'12) was born in Rosario, Argentina, in 1967. He received the Graduate degree in industrial engineering and the Ph.D. degree (cum laude) in industrial engineering from the University of Vigo, Spain, in 1994 and 2003, respectively. He was a Research Assistant at the Applied Electronics Institute, Pedro Barrie de la Maza Foundation, Vigo, in 1994. He has been an Assistant Professor in the Electronic Technology Department, Universidad de Vigo, since 1995 and Associate Professor since 2008. $\mathrm{His}$ current research interests include power electronics for wireless energy transfer and management, switched converter nonlinear modeling, and applied reliability, availability, maintenance, and safety (RAMS) technologies. He is a member of the IEEE Industrial

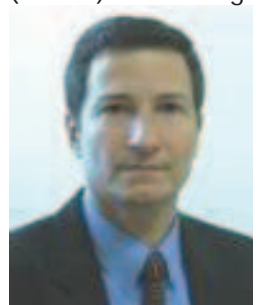
Electronics Society.

João Luiz Afonso (M'00) was born in Rio de J aneiro, Brazil, in 1963. He received the B.S. and M.Sc. degrees in Electrical Engineering from the Federal University of Rio de $J$ aneiro in 1986 and 1991, respectively, and the Ph.D. degree in Industrial Electronics from the University of Minho, Guimarães, Portugal, in 2000. Since 1993, he has been with the Department of Industrial Electronics, University of Minho, where he is Associate Professor. He teaches Electrical Machines, Electrical Energy Systems, Complements of Power Electronics, Electrical Power Quality, Active Power Filters and Renewable Energy. He is a researcher with the Group of Energy and Power Electronics (GEPE), and he coordinates the thematic strand of Sustainable and Smart Cities of the Centro Algoritmi. His research interests include: Power Quality, Active Power Filters, Renewable Energy, Electric Vehicles, Energy Efficiency, Energy Storage Systems, Innovative Railway Systems, Smart Grids and Smart Cities. 